\title{
RECENZJE
}

\section{Robert S. Wójcikouski, Kawaleria perska w okresie wczesnosasanidzkim. Aspekty społeczne i militarne, t. 1: Konnica $w$ Iranie przed Sasanidami, kampanie sasanidzkie, Wydawnictwo Napoleon V, Oświęcim 2014, ISBN: 978-83-7889-257-1, ss. 297}

$\mathrm{M}$ onografia Roberta S. Wójcikowskiego, pierwszy z zapowiadanych przez autora tomów opisujących funkcjonowanie kawalerii w armii Iranu w latach 224-379, to jedna $\mathrm{z}$ najbardziej oryginalnych pozycji o historii starożytności, jakie ukazały się $\mathrm{w}$ minionym roku na polskim rynku wydawniczym. Autor z dużą swobodą operuje skomplikowaną nieraz terminologią, prezentując czytelnikowi rozległą panoramę rozwoju jazdy w Persji od zarania państwowości na Płaskowyżu Irańskim. Praca ma w naszym kraju charakter przełomowy, ponieważ nie było dotychczas monografii poświęconej poszczególnym typom formacji wojskowych w monarchii nowoperskiej. Robert S. Wójcikowski jest absolwentem Uniwersytetu Jagiellońskiego. Obecnie jest związany z Zakładem Historii Starożytnej i Orientalistyki Uniwersytetu Rzeszowskiego. Zajmuje się przemianami politycznymi na Płaskowyżu Irańskim w starożytności, kontaktami Irańczyków z innymi cywilizacjami Eurazji przed nastaniem islamu oraz 
wojskowością irańską w czasach starożytnych. Od wielu lat publikuje, pisząc również na temat Medii jako pierwszego organizmu politycznego na Płaskowyżu o aspiracjach imperialnych ${ }^{21}$.

Autor już we wstępie zaznacza, że w armie starożytnej Persji pozostają niejako w cieniu wobec popularności, jaką wśród badaczy cieszą się wojska Greków i Rzymian. Kawaleria perska była, jak trafnie zauważa badacz, trzonem wojsk wszystkich geopolitycznych odsłon państwowości irańskiej w czasach przedislamskich. W tej sytuacji na szczególne podkreślenie zasługuje fakt, że omawiana publikacja wypełnia znaczącą lukę na polskim rynku.

W pierwszym tomie pracy rzeszowskiego badacza znajdujemy obszerny wstęp zawierający podstawowe informacje na temat metodologii prowadzonych przez niego rozważań, a także szczegółową charakterystykę źródeł, które wykorzystał w pracy. $\mathrm{Na}$ uwagę zasługuje wykorzystanie w pracy warsztatu historyka sztuki i ogromnych pokładów informacji, jakie są wyryte w kamieniu na monumentalnych płaskorzeźbach sasanidzkich władców. Wójcikowski z dużą starannością opisuje każdy z wykorzystanych w swojej pracy reliefów i zestawia opisy dzieł sztuki z pięćdziesięcioma trzema ilustracjami zamieszczonymi we wkładce. Warto zwrócić uwagę na te fotografie, ponieważ charakteryzują się wysoką jakością, co znacznie ułatwia śledzenie ich trafnej analizy przeprowdzonej przez Wójcikowskiego. Należy niestety zauważyć, że dobór ilustracji powoduje pytanie o zasadność umieszczenia niektórych z nich w kompilacji. Autor zamierzał przedstawić dzieła sztuki umożliwiające badania nad uzbrojeniem i funkcjonowaniem jazdy, ewentualnie nad samymi wydarzeniami politycznymi. Taki dobór

${ }^{21} \mathrm{R}$. S. Wójcikowski, Imperium medyjskie - fikcja czy historyczna rzeczywistość, „Miscellanea Eurasiatica Cracoviensia” 2007, s. 269-307; idem, Dejokes - geneza państwa medyjskiego wedtug Herodota, „Nowy Filomata” 2007, 2, s. 117-126; idem, Religia Achemenidów, [w:] Spoteczeństwo i religia w świecie antycznym, red. S. Olszaniec i P. Wojciechowski, Torun 2010, s. 9-18; idem, The Median Empire in Iran and the Fall of Assyria, „Payam-e Bastanshenas. Journal of Archaeology of the Islamic Azad University of Abhar" 2007-2008, vol. 4, no. 8, s. 3-8; idem, Konnica irańska w okresie późnoachemenidzkim, [w:] Hortus Historiae. Księga pamiątkowa ku czci profesora Józefa Wolskiego w setna rocznicę urodzin, E. Dąbrowa, M. Dzielska, M. Salamon, Kraków 2010, s. 123-135. 
artefaktów znajduje uzasadnienie w tytule pracy. Trudno zatem wyjaśnić, dlaczego we wkładce znalazły się zdjęcia przedstawiające ogólny widok grobowca Cyrusa II, mostu trzech cesarzy w Szusztar czy kopii rzeźby, z której zachował się wizerunek głowy Aleksandra Macedońskiego.

Pierwszy rozdział pracy, Rola konnicy $w$ Iranie przed Sasanidami, to sporządzona przez autora historyczna analiza ewolucji taktyki i uzbrojenia jazdy irańskiej na przestrzeni dziejów w okresie panowania Achemenidów, $\mathrm{w}$ czasie dominacji monarchii hellenistycznych i podczas panowania Arsacydów. Już ten rozdział potwierdza innowacyjność publikacji na polskim rynku wydawniczym, ponieważ podobna analiza (jednak ogólniejsza, bez podkreślania roli konnicy) została przeprowadzona wcześniej tylko w książce Marka Woźniaka z 2010 roku $^{22}$. W prowadzonej przez autora narracji zwraca uwagę wysuwająca się na plan pierwszy teza dotycząca rozwoju konnicy w Iranie. Wójcikowski przypomina, że potężna formacja ciężkozbrojnych sasanidzkich jeźdźców nie ewoluowała bezpośrednio na Płaskowyżu i nie była stricte irańskim wynalazkiem. Zdaniem badacza była ona inspirowana w równej mierze macedońską formacją hetajrów, jak i doświadczeniem środkowoazjatyckich ludów, polegającym na prowadzeniu wojen masami konnicy. Wyjaśnia on czytelnikowi, że budzący grozę katafraktowie pojawili się na polu walki dopiero w armii Antiocha III po jego słynnej wschodniej ekspedycji i nie są wytworem myśli wojskowej potomków Cyrusa ${ }^{23}$. Autor zauważa także, że dopiero w czasach Arsacydów w armii irańskiej wyraźna stała się dominacja konnicy ${ }^{24}$. Źródeł potęgi sasanidzkiej jazdy dopatruje się także w partyjskim, a nie achemenidzkim dziedzictwie taktyki wojennej, bowiem zamiast stosowanych wcześniej ogromnych mas mało mobilnej piechoty na pierwszy plan wysunęła się jazda. Wójcikowski celnie punktuje partyjskie korzenie sasanidzkiej jazdy: symboliczne podkreślanie przez dynastię staroperskiego pochodzenia, kastową strukturę ich armii oraz środkowoazjatycką doktrynę ataków klinem

${ }^{22}$ M. Woźniak, Armie starożytnej Persji od powstania państwa Achemenidów do upadku Imperium Sasanidzkiego, Zabrze 2010.

${ }^{23}$ R. S. Wójcikowski, Kawaleria perska w okresie wczesnosasanidzkim. Aspekty spoteczne i militarne, t. 1: Konnica $w$ Iranie przed Sasanidami kampanie sasanidzkie, Oświęcim 2014, s. 147.

${ }^{24}$ Ibidem, s. 153-154. 
ciężkiej jazdy ${ }^{25}$. Zaznacza także, że dla Arsacydów sąsiedztwo nomadów ze stepów Azji Centralnej było kulturowym pomostem między własną przeszłością a staroperską tradycją, do której się odwoływali i do której aspirowali. Słusznie zwraca uwagę na fakt, że podtrzymywanie wzorca konnego prowadzenia wojny w Iranie miało także źródło w istnieniu niezwykle rozległych terytorialnie monarchii Kuszanów i królestw Indo-Partów, które utrzymywały polityczną niezależność od Ktezyfontu w zasadzie aż do czasu panowania Ardaszira I i Szapura I ${ }^{26}$. W tym rozdziale brakuje jednak choćby próby prezentacji elementów taktyki lub uzbrojenia pochodzących z tego regionu, które miały wpływ na jazdę Sasanidów w latach 224-379. Ta luka jest dość ciekawa w kontekście, na pewno znanych Wójcikowskiemu, prac Marka Olbrychta, który w królestwach indopartyjskich upatruje protoplastów Sasanidów ${ }^{27}$. Kończąc rozdział poświęcony ewolucji konnicy w Persji, autor podsumowuje panowanie Arsacydów w Iranie niezwykle pozytywnie. Wymienia sukcesy Partów: wypchnięcie Seleucydów z Iranu, wstrzymanie inwazji koczowników i trwałe powstrzymanie rozwoju rzymskiego Imperium Orientis. To kilkukrotne wyróżnienie wpływu Arsacydów na kształt monarchii Sasanidów wpisuje pracę Wójcikowskiego w dominujący obecnie w nauce nurt, który za Pourshariati upatruje w czasach po panowaniu Ardaszira I sasanidzko-partyjskiej konfederacji, a nie „czystej” monarchii nowoperskiej ${ }^{28}$.

W rozdziale drugim autor przedstawia wszystkie kampanie wojenne Sasanidów przeprowadzone w latach 224-379. I są to opisy kampanii od czasów wojny Ardaszira z Arsacydami po wielką wyprawę Juliana Apostaty do Persji. Rozdział ten jest bardzo interesujący ze względu na opisy kampanii rzadko wspominanych lub całkowicie omijanych przez polskich uczonych. Jako przykłady wystarczy podać ciekawie nakreślone przez autora wyprawy Ardaszira przeciwko Hatrze i Armenii z lat 227-228, podbój Kusznaszahru

25 Ibidem.

${ }^{26}$ Ibidem, s. 155.

${ }_{27}$ M. Olbrycht, Iran Starożytny, [w:] Historia Iranu, red. A. Krasnowolska, Wrocław 2010, s. 192-193; M. Olbrycht, Imperium Parthicum. Kryzys $i$ odbudowa państwa Arsakidów w pierwszej potowie pierwszego wieku po Chrystusie, Kraków 2013, s. 129-131.

${ }^{28}$ P. Pourshariati, Decline and Fall of the Sasanian Empire. The Sasanian-Parthian Confederacy and the Arab Conquest of Iran, New York 2008. 
przez Szapura I z lat 240-241 i ekspedycję arabską Szapura II z 325 roku. W obszernym rozdziale znalazło się jednakowoż kilka zastanawiających sformułowań i potknięć, nad którymi warto się pochylić w recenzji. W opisie panowania Ardaszira autor dwukrotnie nawiązuje do wojny, którą z Partami prowadzili cesarze Karakalla i Makryn. Za każdym razem inaczej ją datuje. We wstępie do rozdziału o panowaniu Ardaszira pisze: „W 217 r. rozpoczęła się kolejna wojna Partii z Rzymem, zakończona świetnym irańskim zwycię-

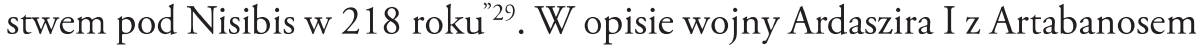
IV konflikt Rzymu i Partii zmienia jednak zakres czasowy: „Dokumenty opisujące wojnę rzymsko-partyjską w latach 216-218, a więc wydarzenia bezpośrednio poprzedzające upadek władzy Arszakidów w Iranie (220-224), wielokrotnie wspominają o jeździe jako jednostce typowej dla armii partyjskiej”" ${ }^{30}$. Szereg przykładów wskazuje także na niestaranną korektę, np. druga wojna Ardaszira z Rzymem z lat 238-240 przesunięta została na rok 328 $(\text { sic! })^{31}$. Podobnie w przypisie 192 , w którym autor opisuje analogię koregencji aktualnego władcy z wytypowanym następcą. O ile Cyrus II i Kambyzes panowali w latach 559-530 i 530-522 przed Chr., to zdobycie przez obu Achemenidów Babilonu i koronacja Kambyzesa na władcę Babilonii następuje już w latach 239 i 238 przed Chrystusem ${ }^{32}$. Rzeszowski badacz uznaje, że konflikt Szapura z Rzymem był w propagandzie prezentowany jako odbicie walki Dobra i Prawdy, po stronie której opowiadał się sasanidzki monarcha, ze Złem i Kłamstwem reprezentowanym przez Rzym, co dobrze wpisywało się w religijne pojmowanie władzy królewskiej w Iranie doby wczesnych Sasanidów ${ }^{33}$. Z tym twierdzeniem autora trudno się nie zgodzić, jednak mało przekonująca jest użyta do jego uzasadnienia literatura, ograniczona tylko do ogólnej syntezy Daryaee ${ }^{34}$. Warto byłoby przytoczyć w tym miejscu choć jeden fragment z Awesty, wskazujący na konieczność walki

\footnotetext{
${ }^{29}$ R. S. Wójcikowski, Kawaleria perska..., s. 176.

${ }^{30}$ Ibidem, s. 179.

31 Ibidem, s. 193.

32 Ibidem, s. 197.

33 Ibidem, s. 211.

${ }^{34}$ T. Daryaee, Sasanian Persia: rise and fall of the empire, New York 2009, s. 7-8.
} 
z tymi, którzy na czcicieli Ahura Mazdy podnoszą rękę̧ . Trzeba także zaznaczyć, że ideologię władzy monarszej, w tym koncepcję chwareny, dokładnie wyjaśnił w 2003 roku Abolala Soudavar ${ }^{36}$. Kolejną kwestią, która wymaga komentarza, jest opis panowania Wahrama I (272-276). Wójcikowski wskazuje, że Aurelian po spacyfikowaniu palmyreńskiego separatyzmu odzyskał inicjatywę na wschodzie i wypowiedział wojnę Iranowi w 275 roku. Autor komentuje ten fakt jako rzymską operację prewencyjną przeciwko Sasanidom, którzy mieli wspierać Zenobię w wojnie z Rzymem ${ }^{37}$. Kłopot w tym, że do konfliktu między mocarstwami we wspomnianym okresie nie doszło, o czym zresztą on sam poinformował czytelnika w ustępie poświęconym Hormizdowi I i wojnie Aureliana z Zenobią ${ }^{38}$. Wójcikowski przytoczył stanowisko Matthew P. Canepy ${ }^{39}$, Beate Dignas i Engelberta Wintera ${ }^{40}$ oraz Katarzyny Maksymiuk ${ }^{41}$ w sprawie braku militarnego konfliktu między imperiami, aby w następnym podrozdziale oskarżyć o jego wywołanie Aureliana. Warto więc w tym miejscu przypomnieć fragment Historia Augusta, który mógł posłużyć autorowi za podstawę jego osądu. Jest to fragment listu, który rzekomo miał trafić od Zenobii do Aureliana: „Nie brak nam pomocniczych wojsk perskich, których właśnie się spodziewamy, po naszej stronie są Saraceni i Armeńczycy" ${ }^{42}$. Cytowany fragment należy jednak traktować

35 Jasna XXXII 1 Gatha (przeł. i oprac. Piotr Żyra): „Bądźmy twoimi heroldami Ahura Mazdo! Powstrzymajmy tych, którzy Cię nienawidzą i atakują!”; Jasna XLIV 11: „Na wszystkich innych bogów i ich zanieczyszczonych wyznawców patrzę nienawiścią mojego ducha”; Jasna XLVI 5: „Niech ten, kto jako władca traktuje swoich rannych poddanych, dobrych obywateli ze świętym obowiązkiem oraz jako niezawisły sędzia sprawiedliwie rozsądza każdy spór, rozpoznaje okrutne istoty i zapowiada im zemstę za ich wrogość, zniszczy wrogiego władcę, gdy ten wyruszy, by zesłać na nas cierpienie”.

${ }^{36}$ A. Soudavar, The Aura of Kings. Legitimacy and Divine Sanction in Iranian Kingship, California 2003.

${ }^{37}$ R. S. Wójcikowski, Kawaleria perska..., s. 213.

${ }^{38}$ Ibidem, s. 212.

${ }^{39}$ M. P. Canepa, Two eyes of the Earth, London 2010, s. 101-102.

${ }^{40}$ B. Dignas, E. Winter, Rome and Persia in Late Antiquity. Neighbours and Rivals, Cambridge-New York 2007, s. 25.

${ }^{41}$ K. Maksymiuk, Polityka Sasanidów wobec wschodnich prowincji Cesarstwa Rzymskiego w III w. n. e., Siedlce 2005, s. 87-88.

${ }^{42} \mathrm{HA}$, Aurel., 27. 
jako wybieg anonimowego autora dzieła mający na celu podkreślenie ilości pokonanych przez Aureliana wrogów. Żadne inne źródło nie przekazuje nam informacji, jakoby Armenia i Persja brały udział w sporze Rzymu i Palmyry. O działalności Aureliana na Wschodzie świadczą wprawdzie tytuły: pactator Orientis, restitutor Orientis i restitutor Orbis, ale - co podkreśla Agata A. Kluczek - brak w ówczesnym mennictwie określeń Persicus Maximus ${ }^{43}$. Nic nie wskazuje zatem, aby w ostatnim roku panowania Aureliana Rzym zaatakował Iran. Należy także przypomnieć, że za panowania jego następców, czyli Tacyta (275-276) i Floriana (276), Cesarstwo prowadziło działania militarne we wschodnich prowincjach, ale były one wymierzone w Gotów plądrujących Azję Mniejszą ${ }^{44}$. Merytoryczny błąd pojawia się niestety także w trakcie opisu tragicznych wydarzeń w Mezopotamii z 363 roku. Autor pisze o bitwie wojsk Juliana z wojskiem perskim pod Marangą 22 VII 363 roku, co nie jest prawdą ${ }^{45}$. Julian rozpoczął odwrót spod Ktezyfontu 16 VI, a zginął w walce 26 VI 363 roku $^{46}$. Dość niejednoznaczne jest także zdanie: „Mimo zwycięstwa pod Ktezyfontem Rzymianie nie zdołali szybko zdobyć irańskiej stolicy" ${ }^{47}$. Dla nieprzygotowanego czytelnika może być to sugestia, że Julian zdobył stolicę Eranszahru, co nie nastąpiło. Niepokojąc się przedłużającym oblężeniem, Julian przeprowadził naradę z pozostałymi dowódcami w tej kampanii, Prokopiuszem i Sebastianem. Ze względu na braki zaopatrzeniowe i możliwość walnej bitwy, którą mógł wydać wycieńczonym legionistom Szapur, oficerowie byli przeciwni kontynuowaniu oblężenia, a zrozpaczony Julian zdecydował się na odwrót i spalenie floty Eufratu eskortującej wojska lądowe ${ }^{48}$.

Podsumowując - pierwszy tom pracy rzeszowskiego badacza, mimo bezprecedensowego charakteru książki $\mathrm{w}$ nauce polskiej, niestety nieco rozczarowuje. Wyraźnie widać zaburzone proporcje wewnętrzne książki,

43 A. A. Kluczek, Wizerunek „obcego - wroga” w ikonografii monetarnej. Przyktad mennictwa cesarza rzymskiego Aureliana (270-275), „Antiquitas” 2007, t. 29, s. 308.

${ }^{44}$ K. Maksymiuk, op. cit., s. 92.

45 R. S. Wójcikowski, Kawaleria perska..., s. 227.

${ }^{46}$ Ammianus Marcellinus, XXV 3, 6-7; Libanius, Or., XVIII 268; Chronicon Paschale, s.a., 363; Theophanes AM 5871, Zonaras XIII, 13.

${ }^{47}$ R. S. Wójcikowski, Kawaleria perska..., s. 227.

${ }^{48}$ Ammianus Marcellinus XXIV 7, 4; Libanius, Or., XVIII, 262. 
z której zresztą de facto nie dowiadujemy się właściwie nic o zapowiadanych w tytule aspektach społecznych funkcjonowania irańskiej jazdy, mimo że podkreślmy raz jeszcze - sugeruje to tytuł pracy. Dokładne, ale nie zawsze potrzebne, historyczno-artystyczne analizy płaskorzeźb rozciągają wstęp książki do prawie osiemdziesięciu stron. Wprawdzie wszystkie opisy są niezwykle szczegółowe i sporządzone zgodnie z zasadami opisu dzieła sztuki, ale w niektórych przypadkach pojawia się pytanie o sens ich zamieszczania. Podobnie rzecz ma się z doborem ilustracji. Zwracają także uwagę kwestie merytoryczne w głównej części narracji, dokładnie już zanalizowane powyżej. Podsumowując, uznaję, że wszyscy zainteresowani wschodnią polityką Rzymu i Iranem Sasanidów powinni tę pracę przeczytać choćby ze względu na ogrom kwerendy i erudycję autora. Opisane niedopatrzenia sprawiają jednak, że pracę należy czytać niezwykle uważnie i podchodzić z dystansem do niektórych zamieszczonych przez autora informacji i tez.

Tomasz Sińczak (Toruń)

\section{Wołodymyr Pyłypenko, W obliczu wroga. \\ Polska literatura antyturecka od połowy XVI do połowy XVII wieku, tłum. Piotr Tafiłouski, Wydawnictuo Napoleon V, Oświęcim 2016, ISBN 978-83-65495-26-6, ss. 192} pozycji wydanej w 2014 roku w Kijowie ${ }^{1}$. Wcześniejsze publikacje

${ }^{1}$ V. Pilipenko, Pered licem voroga: pol'ska antiturec'ka literatura seredini XVI-seredini XVII st., Kiïv 2014, ss. 231. 